\title{
Some Factors Influencing Tobacco Leaf Senescence*
}

\author{
by Donald W. DeJong and William G. Woodlief \\ Tobacco Research Laboratory, Agricultural Research, Science and Education Administration, \\ U.S. Department of Agriculture, Oxford, North Carolina, U.S.A.
}

\section{INTRODUCTION}

In spite of many studies of the phenomenon of leaf senescence, mudh remains to be learned about this important process. Leaf senescence is a naturally occurring phase in all plants and in tobacco it is a normal part of the ripening-curing sequence. For that reason one would expect senescence to be subject to metabolic control. One group of plant growth regulators - the cytokinins - inhibits senescence, whereas another type of regulator, specifically ethylene, promotes senescence. The mechanism for these hormonal effects is not well understood. Nor is it known to what extent a balance between naturally occurring hormonal substances plays a role in leaf maturation. One of the most obvious visible effects of leaf senescence is the change of color from green to yellow, resulting from the degradation of chlorophyll. Another effect evident at the cellular level is the loss of nucleic acids and protein caused by the rise in hydrolytic enzyme activity. In leaves that display a climacteric rise in respiration such as in fluecured type tobacco, an increase in amylase activity triggers the conversion of stored stard to sugar. When tobacco leaves are harvested and cured, these degradative processes are arrested at some intermediate stage, depending upon the tobacco type and method of post-harvest handling. Tobacco genotypes differ with respect to their senescence patrerns - pale yellow types, for example, exhibit a tendency to grow faster and mature earlier than commercial green cultivars (5). Pale yellow tobaccos also ripen more uniformly than other types, with the result that upper leaves can be harvested soon after or even simultaneously with lower leaves (3). If these differences in behavior were better understood, it might be possible to exploit them for harvesting purposes.

One of the objectives of these experiments was to attempt to understand the interaction of light and applied themi-

\footnotetext{
* Cooperative investigations of the Oxford Tobacco Research Laboratory, Federal Researd, Science and Education Administration, U. S. Department of Agriculture, Oxford, North Carolinz, and North Carolioz Stare University, Raleigh, North Carolina. Paper $\mathbf{3 6 6 0}$ of the Journal Series of the North Carolina Agricultural Experiment Station, Raleigh, North Carolinz, U.S.A.

Received: 2nd October $1978 \rightarrow$ accepted: 26th April 1979.
}

cals on leaf yellowing in leaf disks from NC-95 and pale yellow plants. In other experiments, leaves were detadhed and exposed to ethylene in order to trigger the senescence process. Comparisons were made between attaded and detached half-leaves in order to ascertain whether the enzymatic changes resulting from induced senescence were similar in the two genotypes. The climacteric type tesponse of tobacco leaves to ethylene has been documented by Sisler and Pian (15).

\section{EXPERIMENTAL}

\section{Plant material}

Two genotypes of Nicotiana tabacum L. were used. $\mathrm{NC}-95^{+}$, a flue-cured tobacco type standard, and a pale yellow hybrid resulting from crossing NC-95 $\times$ 'T.I. $1372^{++}$were grown in environmental dhambers under conditions previously described (5). Leaves were harvested from mature plants as necessary for experiments and from stalk positions designated in the sequel.

\section{Chlorophyll Loss}

The time course of yellowing was investigated by floating leaf disks in water or aqueous solutions (to be described in the sequel), exposing to light of varying quality and measuring the amount of dhlorophyll remaining after intervals of up to 4 days. The experimental arrangement was as follows: Plants were selected for uniformity in appearance 1-3 weeks after topping. Four leaves from lower stalk positions were harvested together and leaf disks were simultaneously punched out of 4 layers of leaf. Disks ( $9 \mathrm{~mm}$ diameter) chosen at random, were placed into semicircular petri dishes $(12 \mathrm{~cm}$ diameter) containing $50 \mathrm{ml}$ of fluid. The petri dishes were paired, put into $15 \mathrm{~cm}$ plastic pots, which in turn were placed in a $40 \mathrm{~cm} \times 50 \mathrm{~cm}$ plastic tray and covered with a glass plate. Flood lamps ( 100 watt) of various types were suspended $58 \mathrm{~cm}$ above the petri dishes. The material was kept from

\footnotetext{
+ North Carolina

++ Tobacco Introduction
} 
overheating by running tap water through the tray and blowing a stream of air over the set-up with a fan. By this means, the temperature was maintained at $25-30^{\circ} \mathrm{C}$. Four variations of lighting were used: blue light, red light, ultraviolet light and far-red light; the lamps were all obtained from commercial sources. Aqueous solutions used for floating the leaf disks consisted of the following: EDTA-disodium salt at $50 \mathrm{mM}$, magnesium chloride at $50 \mathrm{mM}$, calcium dhloride at $50 \mathrm{mM}$ and kinetin at $5 \mathrm{mg} / \mathrm{l}$.

At sampling time, the leaf disks were homogenized in about $25 \mathrm{ml}$ of acetone with a mortar and pestle. The volume was brought to $50 \mathrm{ml}$ acetone in a volumetric tube. After heating to $60^{\circ} \mathrm{C}$ for $5 \mathrm{~min}$ to destroy enzyme activity and settle the starch and cellular debris, chlorophyll content in the upper clear layer was determined by the method of Aron (2).

\section{Enzyme Changes}

Half-leaves were excised from upper and lower stalk positions (\#3 or 4 and \#9 or 10) 1 week after topping to 12 leaves. The samples were weighed and hung in a conventional laboratory hood with the door closed for 3 days during which time they were gassed with ethylene produced by an ETHYGen Catalytic Generator*. Ethylene concentration was maintained at about $250-500 \mathrm{ppm}$. After the exposure period, the untreated still attached companion half-leaves were then taken from the plants and these, together with the previously detached treated half-leaves, were weighed and used for enzyme extractions. A sample of $5.0 \mathrm{~g}$ laminar tissue was cut from the fresh half-leaves and a $5.0 \mathrm{~g}$ equivalent (correcting for moisture loss) sample was taken from the treated halfleaves.

\section{Enzyme extracts were prepared as follows:}

1. Leaf tissue was homogenized in $15 \mathrm{ml}$ of $50 \mathrm{mM}$ HEPES buffer at $\mathrm{pH} 7.5$ containing $15 \mathrm{mM}$ EDTA, $15 \mathrm{mM}$ sodium diethyldithiocarbamate for $1 \mathrm{~min}$ at 40,000 r.p.m. in a Virtis \#60 homogenizer. After Miracloth filtering, the homogenate was centrifuged at $17,000 \times \mathrm{g}$ for $30 \mathrm{~min}$. The supernatant was used as the enzyme source for alphaamylase, protease, leucine amino-peptidase and esterase.

2. Alternatively, leaf tissue $(5.0 \mathrm{~g})$ was homogenized in $15 \mathrm{ml}$ of $0.1 \mathrm{M}$ potassium phosphate buffer at $\mathrm{pH} 7.5$ containing $0.5 \mathrm{M}$ sucrose for $1 \mathrm{~min}$ at 40,000 r.p.m. in a \#60 Virtis homogenizer. The preparation was filtered through Miracloth and centrifuged. The supernatant was used as an enzyme source for chlorogenic acid oxidase and glycolate oxidase.

\section{Enzyme assays were performed as follows:}

Esterase activity was assayed by measuring the rate of release of phenolphthalein from its dibutyrate ester. Enzyme in a $1 \mathrm{ml}$ volume was combined with $2.5 \mathrm{ml}$ of Tris-

\footnotetext{
- Mention of a trademark or proprietary product does not conttitute a guarantee or wartanty of the prodyct by the U. S. Department of Agriculture, and does not imply its approval to the exclusion of ocher products that may also be suikable.
}

$\mathrm{HCl}$ buffer (pH 8.3 at $0.1 \mathrm{M}$ ) and equilibrated at $37^{\circ} \mathrm{C}$ for $10 \mathrm{~min}$. Then, $0.5 \mathrm{ml}$ substrate was added and the enzyme mixture was incubated for 2 hours at $37^{\circ} \mathrm{C}$. At periodic intervals, $1 \mathrm{ml}$ aliquots were withdrawn and mixed with $0.5 \mathrm{ml}$ of $20 \%$ cold trichloroacetic acid. After centrifuging, $0.5 \mathrm{ml}$ of the supernatant was added to $1.0 \mathrm{ml}$ of $0.5 \mathrm{~N} \mathrm{NaOH}$ and vigorously swirled. The optical density measured at $554 \mathrm{~nm}$ was related to enzyme activity for each time interval.

Alpha-amylase was assayed by the reagents and methods provided in the Pierce Rapid-Stat Kit. A $50 \mu$ l enzyme solution was combined with $500 \mu \mathrm{l}$ of the substrate and incubated at $25^{\circ} \mathrm{C}$ for $30 \mathrm{~min}$. After incubation, the mixture was combined with $500 \mu \mathrm{l}$ of color reagent, heated for $10 \mathrm{~min}$ in a boiling water bath, cooled and combined with $4.0 \mathrm{ml}$ of water. The absorbance at $500 \mathrm{~nm}$ was measured to determine the enzyme activity.

Leucine amino-peptidase (LAP) was assayed by the reagents and methods supplied with the Sigma Diagnostic Kit for LAP. A $0.2 \mathrm{ml}$ aliquot of enzyme solution was combined with $1.0 \mathrm{ml}$ of $0.1 \mathrm{M}$ potassium phosphate buffer at $\mathrm{pH} 7.0,0.3 \mathrm{ml}$ of $0.15 \mathrm{M} \mathrm{NaCl}, 0.3 \mathrm{ml}$ of water, and $0.2 \mathrm{ml}$ of substrate. After incubating for $30 \mathrm{~min}$, $1.0 \mathrm{ml}$ of $10 \%$ perchloric acid was added, mixed and centrifuged. A $0.5 \mathrm{ml}$ aliquot of the supernatant was mixed with $0.5 \mathrm{ml}$ of $\mathrm{NaNO}_{2}(2 \mathrm{~g} / 1$ reagent), incubated for $20 \mathrm{~min}$ and combined with $0.5 \mathrm{ml}$ of ammonium sulfamate ( $5 \mathrm{~g} / \mathrm{l}$ reagent). After $2 \mathrm{~min}, 1.0 \mathrm{ml}$ of naphthylethylenediamine reagent was added. After allowing for $30 \mathrm{~min}$ reaction, the absorbance was measured at $578 \mathrm{~nm}$ to determine enzyme activity.

Protease was assayed by measuring the increase in color at $520 \mathrm{~nm}$ resulting from the release of soluble azo dye from insoluble azocoll. The procedure followed was that described in the bulletin supplied with the protease substrate by Calbiochem $\mathrm{Co}$. The reaction mixture contained $5.0 \mathrm{ml}$ of $0.1 \mathrm{M}$ potassium phosphate buffer at $\mathrm{pH} 7.5$ with $1.0 \mathrm{ml}$ of enzyme extract and $2.0 \mathrm{mg}$ of azocoll. The mixture was incubated for 2 hours at $25^{\circ} \mathrm{C}$ with constant stirring. Aliquots were taken at $15,30,60$ and $120 \mathrm{~min}$ to follow the course of the reaction by measuring absorbency at $554 \mathrm{~nm}$. Assays were also run at $\mathrm{pH} 3.0$ as suggested by Martin and Thimann (11) but the patterns were the same and the rate was $1 / 3$ less than that observed at $\mathrm{pH} 7.5$. We concluded that at this stage of leaf development, the major protease activity occurred at $\mathrm{pH} 7.5$.

Chlorogenic acid oxidase and glycolate oxidase were measured polarographically with the Clark electrode and a Ysi apparatus. The reaction mixture for the former consisted of $2.5 \mathrm{ml}$ of $0.1 \mathrm{M}$ phosphate buffer at $\mathrm{pH} 6.0$ with $0.5 \mathrm{ml}$ enzyme and $0.2 \mathrm{ml}$ of $10 \mathrm{mM}$ chlorogenic acid. The reaction mixture for glycolate oxidase consisted of $2.5 \mathrm{ml}$ of $0.2 \mathrm{M}$ borate buffer at $\mathrm{pH} 8.5,0.5 \mathrm{ml}$ of enzyme extract and $0.2 \mathrm{ml}$ of $125 \mathrm{mM}$ sodium glycolate. Temperature bath for both was maintained at $25^{\circ} \mathrm{C}$. No basal $\mathrm{O}_{2}$ uptake was observed in the glycolate oxidase assay (minus substrate) but the non-substrate rate in the chlorogenic acid oxidase assay was substantial and will therefore be reported. 
Figure 1. Rates of chlorophyll degradation in tobacco leaf disks as affected by EDTA - - and water - . -; dark conditions.

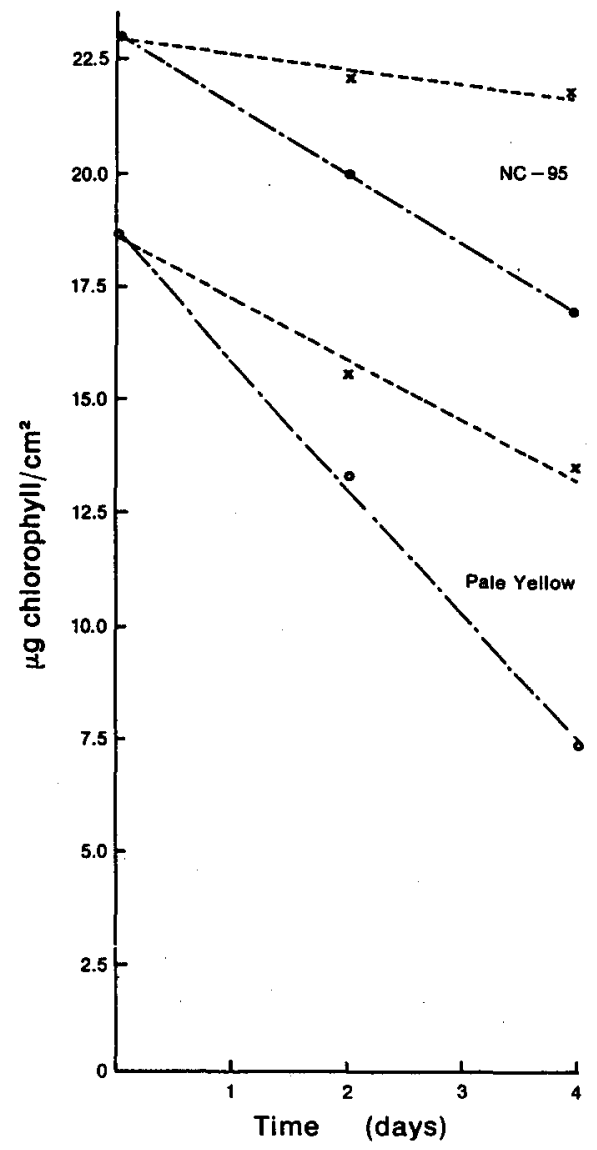

Figure 3. Comparison of chlorophyll loss in tobacco leaf disks subjected to far-red or ultraviolet light for 4 days in presence of water /// or EDTA III solution; dark conditlons: $\mathbf{0}$.

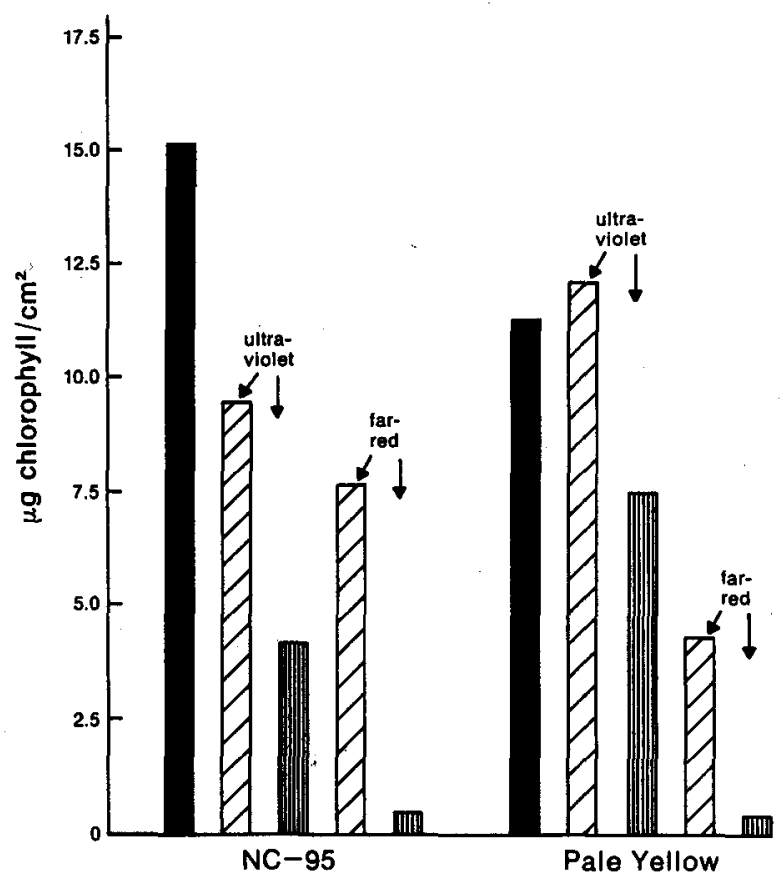

Figure 2. Rates of chlorophyll degradation in tobacco leaf disks as affected by blue $\longrightarrow$ and red ++ light; EDTA solution.

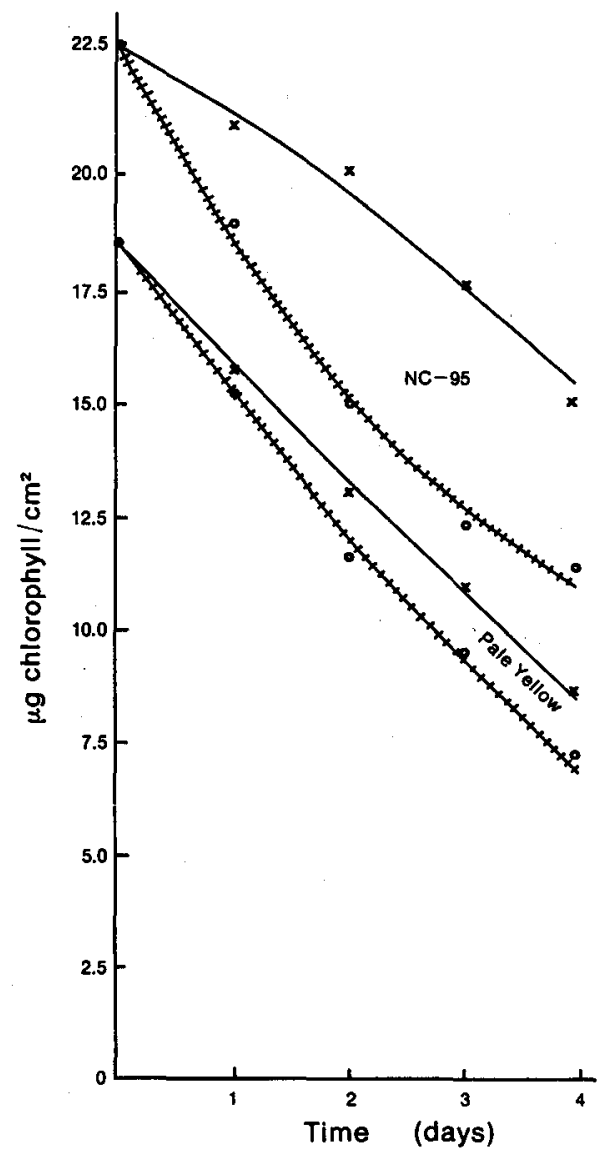

Figure 4. Comparison of chlorophyll loss in tobacco leaf disks subjected to far-red or ultraviolet llght for 3 days in presence of EDTA III or kinetin /I/; dark conditions:

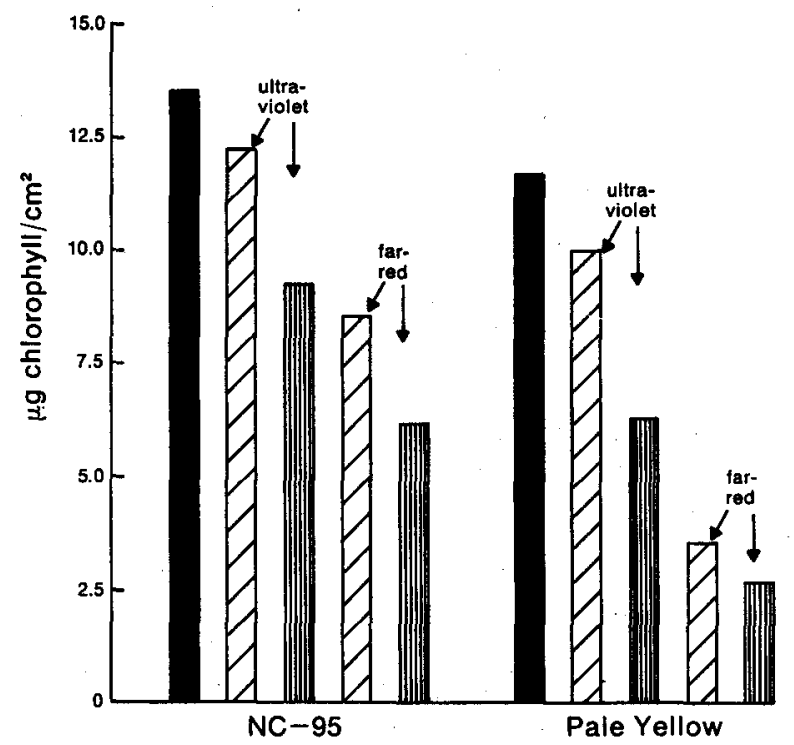




\section{RESULTS}

\section{Chlorophyll Loss}

The rate of chlorophyll loss in the dark is shown in Fig. 1. Pale yellow leaf tissue not only had less chlorophyll initially but chlorophyll also degraded at a faster rate than that of NC-95 - in fact, approximately 1.8 times faster $\left(2.76 \mu \mathrm{g} / \mathrm{day} / \mathrm{cm}^{2}\right.$ versus $\left.1.51 \mu \mathrm{g} / \mathrm{day} / \mathrm{cm}^{2}\right)$. The loss of chlorophyll from leaf disks was inhibited by EDTA in the dark but not in the light (Figures 1 and 2). In conjunction with red light, EDTA enhanced hlorophyll loss, but blue light had little effect on the rate of chlorophyll degradation.

At the extreme ends of the light spectrum, we observed that far-red in the presence of EDTA was considerably more destructive of chlorophyll than was ultraviolet (Fig. 3). The effect was most pronounced in Pale Yellow leaf disks. Far-red light promoted chlorophyll degradation more than did ultraviolet light irrespective of the presence of kinetin or EDTA, although some protection was afforded by kinetin (Fig. 4). In a final experiment to attempt to determine whether or not the effect of EDTA was due to its cation-chelating ability, we tested the effect of addition of magnesium and calcium. As shown in Fig. 5, only magnesium was capable of providing significant protection against chlorophyll degradation in the light. With red light, the protection was complete - no chlorophyll loss from initial starting concentrations. With far-red light, chlorophyll loss was greatest with EDTA. Differences between calcium and water treatments were negligible. In the last two experiments, leaf disks were sampled after only 3 days so chlorophyll was not fully degraded in any of the treatments.

These experiments revealed that far-red light promoted chlorophyll breakdown more than did red, blue or ultraviolet, in that order. Furthermore EDTA protected chloro-

Figure 5. Comparison of chlorophyll loss In Pale Yellow tobacco leat disks subjected to red or far-red light for 3 days in presence of water, magneslum, calclum or EDTA.

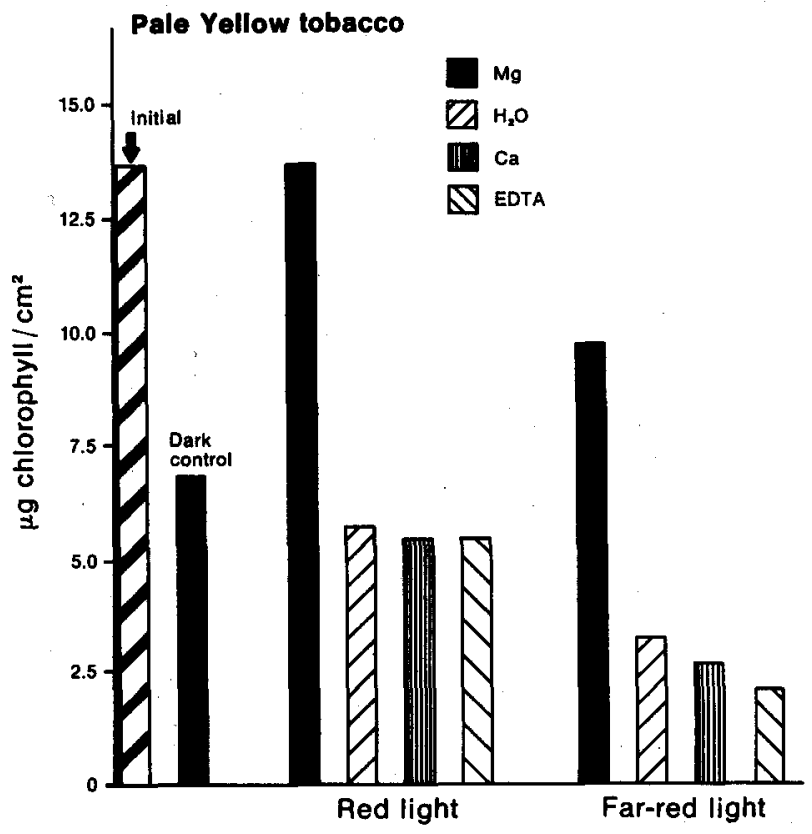

Figure 6. Comparison of chlorophyll photodestruction in vitro by lamps of different quality and intensity after $40 \mathrm{~min}$ exposure.

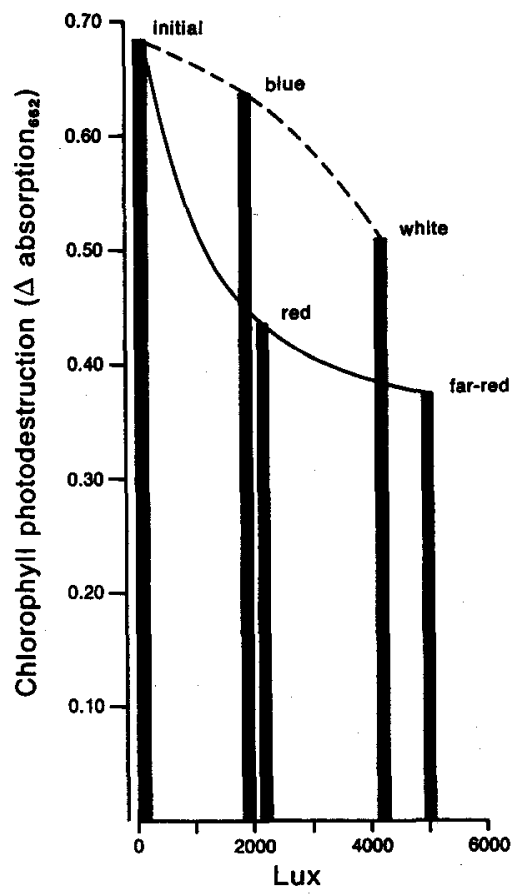

phyll from degradation in the dark but not in the light where it promoted the process.

In experiments to determine the interaction of light quality and intensity on chlorophyll stability, we subjected purified chlorophyll solutions to lamps of different colors and intensities. As shown in Fig. 6, chlorophyll bleaching in extracts was stimulated more by red light than by blue light, confirming the in vivo experiments; white light of comparable intensity was relatively less effective than red light. The time course of chlorophyll photodestruction

Figure 7. Rate of chlorophyll photodestruction in vitro by high Intensity (7500 lux) ultraviolet lamp.

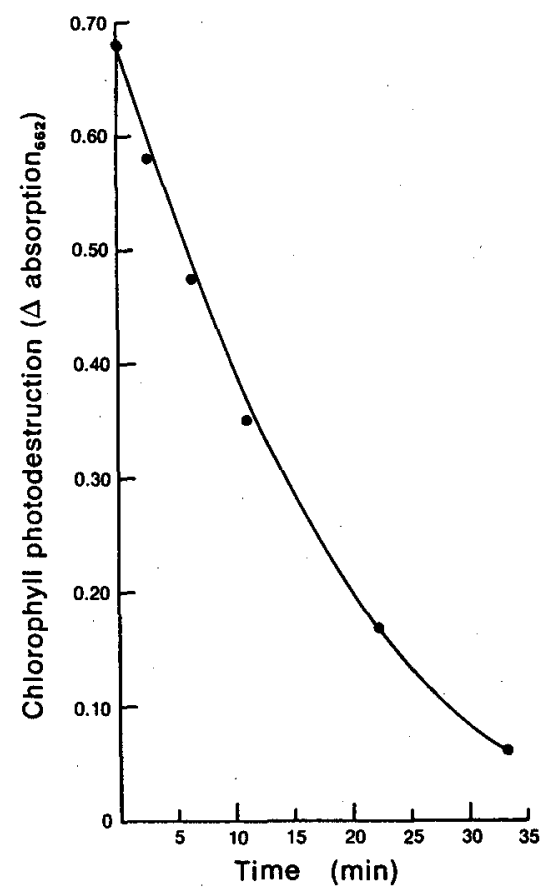


Figure 8. Effect of leaf detachment and exposure to ethylene on eaterase actlvity in Pale Yellow and NC-95 upper and lower leaves. Enzyme units are expressed as $\Delta$ absorption $_{554} / \mathrm{h} / \mathrm{g}$ fresh weight (untreated: III, treated: /I/ ).

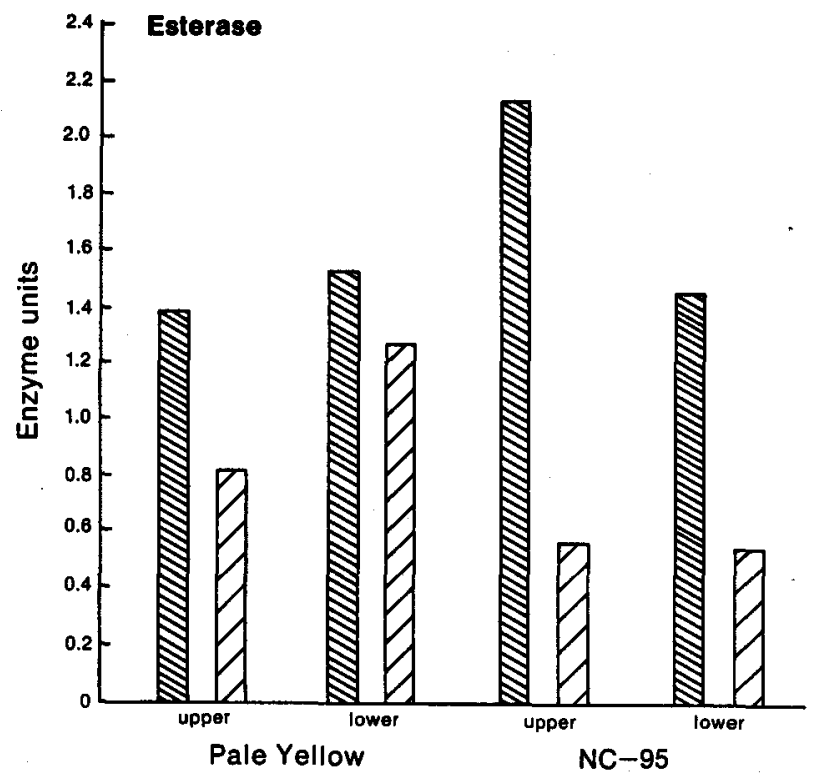

Figure 9. Effect of leaf detachment and exposure to ethylene on alpha-amylase activity in Pale Yellow and NC-95 upper and lower leaves. Enzyme units are expressed as $\mathrm{mg}$ glucose/min/g fresh weight (untreated: III, treated: /II ).

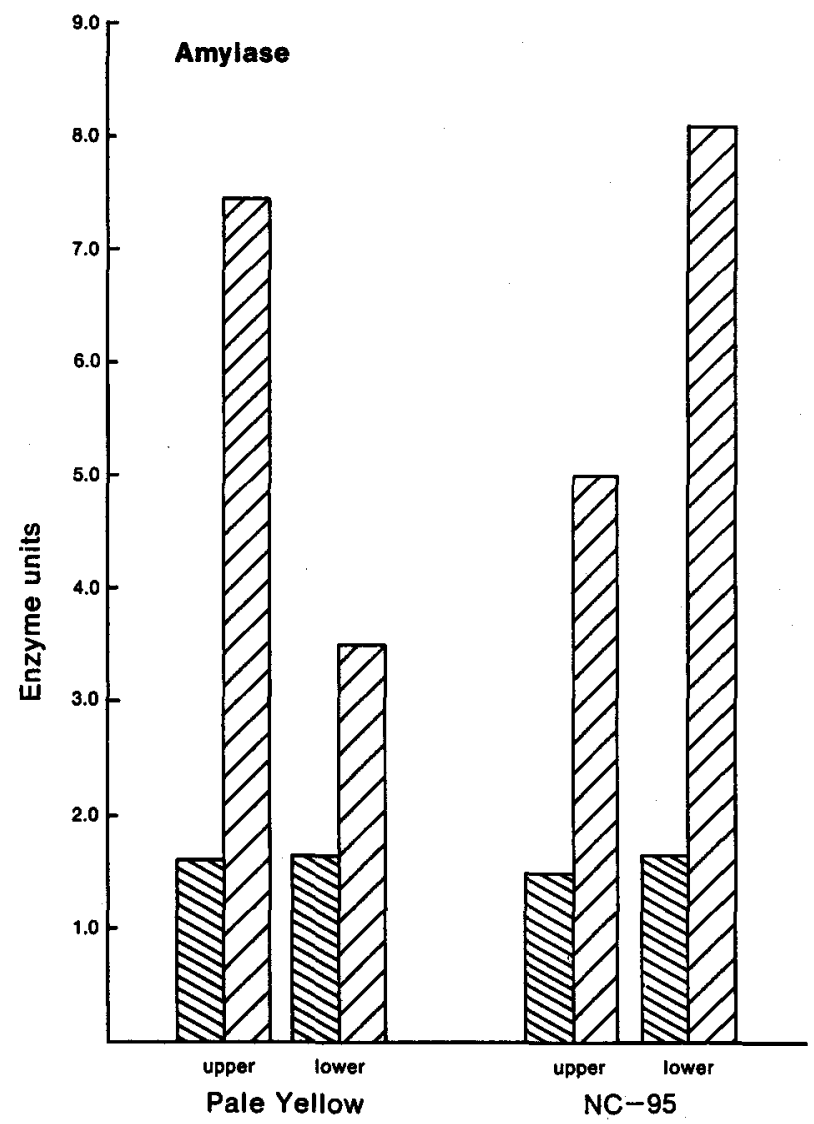

Figure 10. Effect of leaf detachment and exposure to ethylene on protease activity In Pale Yellow and NC-95 upper and lower leaves. Enzyme units are expressed as $\Delta$ absorption $_{520} / \mathrm{h} / \mathrm{g}$ fresh weight (untreated: III, treated: /II).

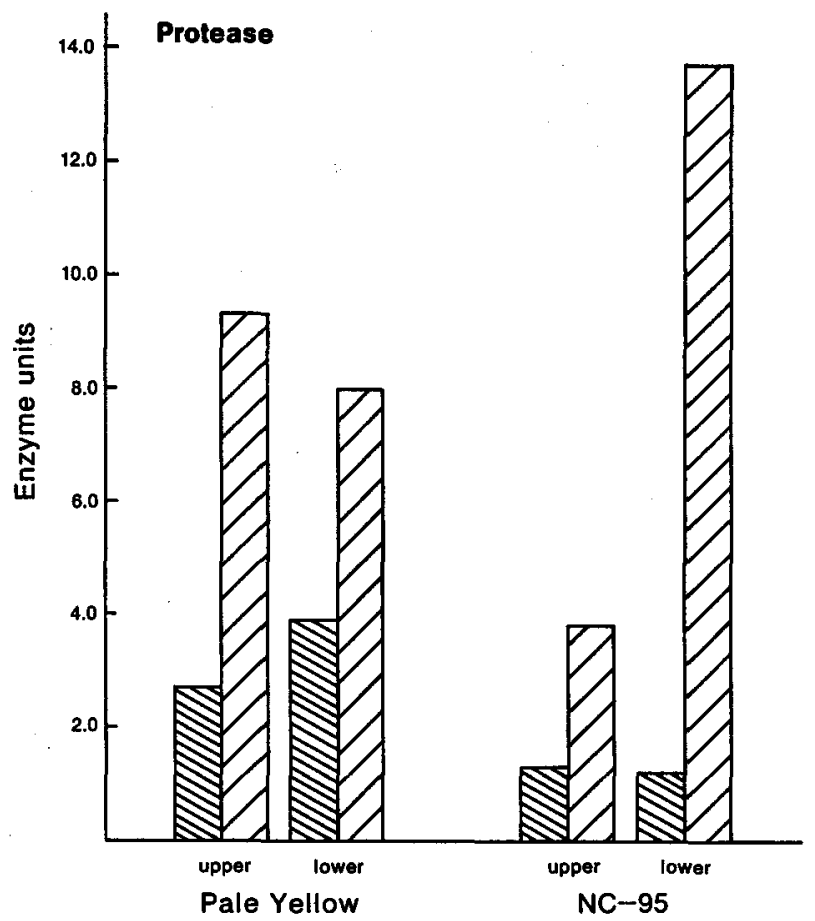

Figure 11. Effect of leaf detachment and exposure to ethylene on leucine amino-peptldase activity in Pale Yellow and NC-95 upper and lower leaves. Enzyme units are expressed as $\mu \mathrm{g}$ naphthylamine $/ \mathrm{min} / \mathrm{g}$ fresh weight (untreated: III, treated: (II).

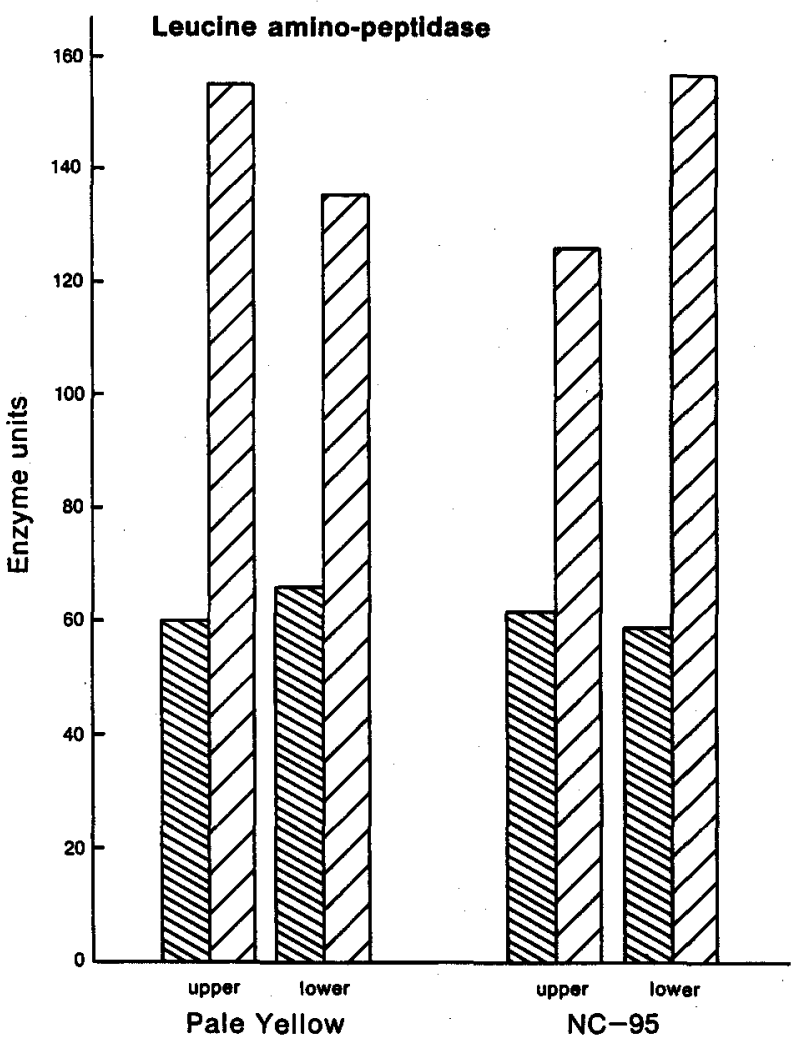


in vitro with high intensity UV light is shown in Fig. 7. Chlorophyll degradation was initially quite rapid and during the first $10 \mathrm{~min}$ was linear; thereafter, the rate began to decrease. Destruction was virtually complete after about $40 \mathrm{~min}$.

\section{Enzyme Changes}

The activities of several hydrolytic and oxidative enzymes were examined in relationship to the induction of leaf senescence by detachment from the stalk and exposure to ethylene. In general, the results demonstrated that while esterase decreased (Fig. 8), amylase, protease, and LAP increased (Figures 9, 10,11) as a result of the treatment. When one compares individual values, it can be seen that the extent of enzyme change varied with leaf position in the two tobacco genotypes studied. For example, the greatest increases in amylase were observed for Pale Yellow upper leaves and NC-95 lower leaves (Fig. 9). The least increase was noted in Pale Yellow lower leaves, which appeared the yellowest of the four samples. The pattern for protease activity was much the same as that for amylase - activity was greatly stimulated by the treatment, particularly in NC-95 lower and Pale Yellow upper leaves (Fig. 10). Leucine amino-peptidase was also

Figure 12. Effect of leal detachment and exposure to ethylene on chlorogenic acid oxidase activity in Pale Yellow and NC-95 upper and lower leaves. Enzyme units are in $\mu$ moles $\mathrm{O}_{2} / \mathrm{min} / \mathrm{g}$ fresh weight (basal rates: untreated $=I I I$, treated $=I I I$; substrate rates: untreated $=I I I$, treated $=$ III).

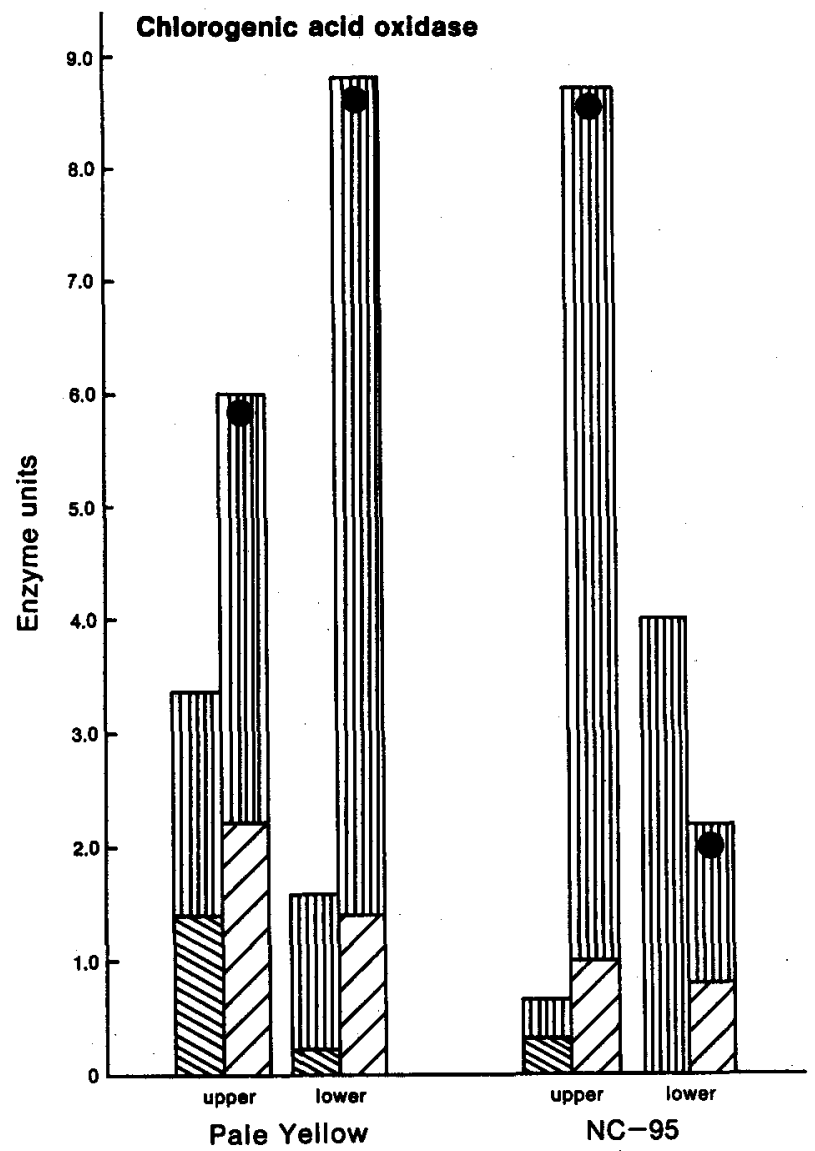

Table 1. Effect of senescence Induction on glycolate oxidase activity * In tobacco leaves.

\begin{tabular}{|c|c|c|c|c|c|}
\hline \multirow[b]{2}{*}{ Leal source } & & \multicolumn{2}{|c|}{ Untreated } & \multicolumn{2}{|c|}{ Treated } \\
\hline & & $\begin{array}{l}\text { homo- } \\
\text { genate }\end{array}$ & $\begin{array}{l}\text { super- } \\
\text { natant }\end{array}$ & $\begin{array}{l}\text { homo- } \\
\text { genate }\end{array}$ & $\begin{array}{l}\text { super- } \\
\text { natant }\end{array}$ \\
\hline $\begin{array}{l}\text { Pale } \\
\text { Yellow }\end{array}$ & $\begin{array}{l}\text { upper } \\
\text { lower }\end{array}$ & $\begin{array}{l}2.40 \\
0.55\end{array}$ & $\begin{array}{l}1.96 \\
0.49\end{array}$ & $\begin{array}{l}1.97 \\
1.33\end{array}$ & $\begin{array}{l}1.81 \\
1.03\end{array}$ \\
\hline NC-95 & $\begin{array}{l}\text { upper } \\
\text { lower }\end{array}$ & $\begin{array}{l}2.21 \\
0.68\end{array}$ & $\begin{array}{l}2.21 \\
0.61\end{array}$ & $\begin{array}{l}2.42 \\
0.71\end{array}$ & $\begin{array}{l}2.43 \\
0.59\end{array}$ \\
\hline
\end{tabular}

- Activity expressed as $\mu$ moles $O_{2}$ uptake $/ \mathrm{min} / \mathrm{g}$ fresh weight with glycolate as substrate. See Experimental for treatment procedure.

increased by the treatment (i.e. averaging 2.5 times more than the control; Fig. 11). The differences seen in LAP activity between treated and untreated NC-95 leaves were not as great as the changes found for amylase and protease activity. In a companion assay, wherein homogenate rather than supernatant was used in the mixture, LAP activity in all samples was somewhat decreased.

The two oxidative enzymes chosen to assess the effects of induced senescence were chlorogenic acid oxidase and glycolate oxidase. Both were assayed polarographically by measuring $\mathrm{O}_{2}$ uptake. Glycolate oxidase was little affected by the treatment (Table 1). Glycolate oxidase activity was usually slightly higher in the homogenate than in the supernatant indicating that the increase in activity was not due to peroxisomal disruption.

The results of treatment on chlorogenic acid oxidase were of special interest because the leaf samples which showed the greatest stimulation of amylase and protease activity, viz. NC-95 lower and Pale Yellow upper, showed the least increase of chlorogenic acid oxidase activity (Fig.12). The basal or non-substrate rate of $\mathrm{O}_{2}$ uptake was always somewhat greater (usually double) in homogenate preparations than in supernatants. Addition of dhlorogenic acid as substrate produced a marked increase in the rate of $\mathrm{O}_{2}$ uptake in all samples except NC-95 lower leaves in which we also observed a decrease in oxidase activity as a result of treatment.

\section{DISCUSSION}

The subject of leaf senescence has continued to motivate substantial research efforts over the years. For many crop plants, it is a limiting factor in production potential. For tobacco, it is the period when the leaves are undergoing changes required before harvest and development of full quality. Under field conditions, leaves of flue-cured tobacco ripen successively up the stalk and are usually harvested in early stages of senescence. The yellowing process is accelerated by gradually increasing the heat from $30^{\circ} \mathrm{C}$ to $45^{\circ} \mathrm{C}$ for a period of 1-3 days. Subsequently, the leaves and stems are dried at temperatures eventually reaching as high as $70^{\circ} \mathrm{C}(8)$. Many factors influence the success with which growers are able to produce leaves of the proper quality. Considerable variation is known to 
exist with regard to tobacco of different genotypes. Some, like the pale yellow types, appear to be difficult to handle by conventional methods in order to achieve the same chemical composition in the cured state. In addition, as other methods of curing are investigated such as Homogenized Leaf Curing it would be interesting to know more about the processes involved in senescence. These primarily relate to color changes - particularly yellowing or browning and the enzymatic activities that play a role in the hydrolytic breakdown of large molecular weight components, primarily starch and protein.

In a recent comprehensive review of senescence, Woolbouse (20) stated that during the P2 stage of leaf development, the chloroplast envelope remains relatively intact and the decline in soluble protein and RNA proceeds gradually at first. During the early phase of $\mathrm{P} 3$ regreening can occur, indicating that the process is initially reversible. Vonshak and Richmond (18) reported that the capacity for protein synthesis by detached tobacco leaves is not irreversibly lost until after 24 hours in the dark.

Anderson and Rowan (1) showed that the senescence of tobacco leaves is accompanied by a loss of protein but an increase in proteolytic activity. Martin and Thimann (11) concluded on the basis of experiments with excised Avena leaves that senescence is an autocatalytic process since the accumulation of free amino acids such as serine and cysteine (to a lesser extent) activates proteolysis. Active metabolism is required for senescence to proceed since yellowing can be blocked by cycloheximide (11) or KCN (10). However, kinetin is effective in slowing senescence of detached leaves only if they are held in the dark. Fletcher and Adedipe (7) suggested that the commonly used cytokinin, benzyladenine, retards leaf senescence by maintaining a high retention of photosynthate, high levels of starch, protein and RNA as well as promoting a high turnover of metabolites. Martin and Thimann (11) proved rather conclusively that kinetin acts by preventing proteolysis rather than by promoting protein synthesis. Skokxt et al. (16) recently found that benzyladenine also retarded the UV-accelerated senescence of $N$. glutinosa L. leaves. There is evidence that the presence of the lower epidermis is required for kinetin retardation of chlorophyll degradation in tobacco leaf disks (9). Similarly, UV-acceleration of leaf chlorosis can be prevented in tobacco leaf disks by peeling off the lower epidermis or floating in water (22). Our work showed that UV light was a poor promoter of chlorophyll destruction in leaf disks, but was quite effective in bleaching chlorophyll solutions (Fig. 7). We attribute these results to the fact that chlorophyll is protected from photodestruction by carotenoids present in intact dhloroplasts. Cell wall breakdown is a phenomenon associated with late stages of leaf senescence. Matile (12) showed that abscisic acid caused a $50 \%$ loss of non-cellulosic wall contents from treated tobacco leaf tissue. Benzyladenine not only delayed the breakdown of this cell wall material, but actually caused a slight increase in the hemicellulosic fraction.

One of the factors that has been implicated in prevention of leaf senescence is calcium $(13,14)$. In our experiments with leaf disks, we found a retardation with magnesium but not with calcium. Kotaka and Kreuger's (10) work on the bleaching effect of EDTA on green barley leaves raised the possibility that it might have been due to removal of magnesium from the chlorophyll molecule but they dismissed this explanation on the basis of experiments with chlorophyll solutions. However, our work has shown that the yellowing effect of EDTA (in the light) might indeed be a result of displacement of magnesium from dhlorophyll. One reason for the inability of calcium to prevent senescence has recently been answered in part by the finding that it appears not to be calcium per se that retards senescence but rather that calcium acts indirectly by its influence on the movement of potassium into the plant (21). To what extent the experimental variables we employed affect the tobacco plant in the field can only be a matter of speculation. However, it does suggest ways for achieving better control of the senescence process so as to facilitate leaf harvesting and storage. This is particularly true of systems such as Homogenized Leaf Curing whidi will require a number of innovations in leaf handling (6).

The enzyme studies presented here suggest that certain tobacco genotypes differ quite remarkably in their ripening sequence. Collectively the data show that considerable increases in enzyme activities, particularly those involved in hydrolytic and oxidative breakdown of cell contents, occur during leaf senescence. This kind of information is not new; however, our results show in a unique way how the degree of response varies according to the stage of leaf development and the genotype of the plant. It is obvious as one looks at the data that at identical chronological ages, lower leaves of NC-95 and Pale Yellow plants are not physiologically the same. Lower leaves of Pale Yellow plants had probably already passed their prime by the time we harvested them and ran the experiments. This may help explain why the reducing sugar content in fluecured pale yellow leaves is invariably low (J. Chaplin, personal communication). It is probable that the process of degradation characteristic of senescence in pale yellow leaves begins earlier than customary with more conventional varieties. On the other hand, it was interesting to note that Pale yellow upper leaves appeared to be at the same state of physiological maturity as NC-95 lower leaves, since they responded in a similar way to the treatment. In addition, the failure of NC-95 upper leaves to respond in the same degree as the other leaves simply means that they are the least physiologically mature of the four leaves tested. The significance of dilorogenic acid oxidase levels in the samples is not clear. We have shown previously that ethylene (as ethephon (2-chloroethyl phosphonic acid)) treatment of NC-95 lower leaves decreases activity (4); however, in these studies we also examined the effect on upper leaves and found that with these leaves the opposite is true; namely that a marked stimulation of chlorogenic acid oxidase occurs in response to ethylene. This means that although these leaves are not mature enough to respond fully to senescence-inducing factors, they nevertheless do react to stress, such as detachment (perhaps as a wounding response) and exposure to ethylene. Another anomaly with this enzyme 
was that Pale Yellow lower leaves which were presumably in a late stage of senescence were still capable of generating a substantial increase in dolorogenic acid oxidase activity, much more so in fact than upper leaves from the same plant. The high basal rate of $\mathrm{O}_{2}$ uptake we believe to be indicative of particulate (or mitochondrial) respiration although we were unable to detect succinoxidase. Most of the increase in basal rate was cyanide insensitive and therefore probably due to the alternate or non-cytochrome pathway (18). The data indicate that although chlorogenic acid oxidase can be induced by leaf detachment and exposure to ethylene, it can hardly be regarded as an important enzyme in senescence. We draw this conclusion in spite of data which show it to be the most important enzyme involved in the oxidative browning of crushed tobacco leaves (19). It would appear from our results that whereas chlorogenic acid oxidase activity tends to decrease during maturation of $\mathrm{NC}-95$ leaves, it seems to increase during maturation of Pale Yellow leaves. This may be the reason why homogenates of mature pale yellow leaves always show a greater tendency toward darkening - particularly in the Homogenized Leaf Curing system (unpublished results). Although pale yellow tobacco exhibits a number of advantages in handling by means of the Homogenized Leaf Curing method, oxidative browning is more difficult to control in the pale yellow tobacco genotype and presents a problem in this regard.

Pale yellow tobacco appears to peak very early in its potential for amylolytic and proteolytic activity. The fact that upper leaves of this plant were capable of very large increments in enzyme activity indicates that they may be ready for processing far sooner than we have previously thought. It appears obvious that tobaccos like the pale yellow lines must be handled quite differently from conventional cultivars if they are to be utilized commercially. Furthermore, experiments designed to establish yield and quality that treat all the tobacco entries identically without taking their physiological differences into consideration are probably not very adequate for demonstrating the real potential of these types of tobacco. Conditions for growing, harvesting, and curing may have to be altered in order to exploit them commercially. Certainly it appears obvious that pale yellow tobaccos have two utilitarian advantages over conventional cultivars. These are: [1] earlier maturation and [2] more uniform ripening. The latter trait in particular might be amenable to once-over harvesting. However, in order to keep the sugar levels high enough, pale yellow leaves would have to be harvested earlier than usual to avoid overripening and yellowed rapidly. The problem of high alpha-amino nitrogen could be dealt with by a protein removal process such as that suggested recently in conjunction with Homogenized Leaf Curing $(6,17)$. However, its high browning potential resulting from the increase in chlorogenic acid oxidase during maturity probably will necessitate the use of more effective antioxidants. Fundamental studies of leaf metabolism during the critical phase of leaf senescence are essential for identifying the impact of genetic manipulation and cultural practices on certain biodhemical aspects of tobacco production. We have endeavored to focus on several factors - both physical and demical - that could be involved in influencing leaf development. Some of these factors delay senescence; others accelerate it. In order to alter tobacco processing in a rational manner, it is also important to understand the role of enzyme systems in changing the chemistry of the leaf during advanced stages of leaf maturation. These efforts should enable us to design the proper conditions for introducing technological innovations for producing tobaccos of improved usability.

\section{SUMMARY}

Tobacco leaf disks were subjected to various types of lighting and demical solutions to determine the interaction of these factors in leaf senescence. Far-red light promoted senescence more than light of lower wavelengths. Magnesium at $50 \mathrm{mM}$ was a potent inhibitor of senescence, whereas EDTA-disodium salt at $50 \mathrm{mM}$ promoted senescence in the light but retarded senescence in the dark. Additional work with the effect of ethylene on detadhed leaves demonstrated that hydrolytic enzyme activity for amylase, peptidase and protease increased as a result of treatment but esterase activity decreased. The response differed with regard to variety and leaf maturity. Exposure to ethylene increased chlorogenic acid oxidase in lower leaves of pale yellow tobacco but decreased the enzyme in NC-95 lower leaves. These data relate to the growth behaviour of the two genotypes in that physiological maturity occurs at considerably different rates in pale yellow and NC-95 plants. The results help to explain why leaves of pale yellow plants tend to ripen within a mudh shorter time than leaves of conventional green tobacco cultivars.

\section{ZUSAMMENFASSUNG}

Tabakblattausschnitte wurden mit verschiedenen Arten von Beleuchtung und chemischen Lösungen behandelt, um den Einfluß dieser Faktoren auf den Reifungsprozeß zu erforschen. Langwellige Infrarotstrahlung beschleunigte die Alterung stärker als Licht mit kürzeren Wellenlängen. Magnesium in der Konzentration von $50 \mathrm{mM}$ wirkte der Alterung stark entgegen, während das Dinatriumsalz von EDTA (50 $\mathrm{mM}$ ) die Blattalterung mit Lidhteinfluß begünstigte, im Dunkeln jedoch hemmte. Dariber hinaus wurde untersucht, welchen Einfluß die Anwendung von Ethylen auf Blattgut ausibt, das von der Sproßachse abgetrennt ist. Es zeigte sich, daß die Aktivität der Amylase, Peptidase und Protease durch die Behandlung abgetrennter Blätter mit Ethylen zunimmt, während die Esteraseaktivität abnimmt. Die Reaktion fiel nach Tabakart und Reifegrad des Blattgutes verschieden aus. Durch Einwirkung von Ethylen nahm die Chlorogensäureoxidase in den unteren Blättern weißgelber (pale yellow) Tabaksorten $\mathrm{zu}$, während sie sich in den unteren Blättern der Tabaksorte NC-95 verringerte. Was das Wachstum dieser beiden Genotypen anbetriff, zeigen die Befunde, daß der 
physiologische Reifungsprozeß bei weißgelbem Tabak und bei NC-95-Tabak zeitlich sehr unterschiedlich verläuft. Die Ergebnisse tragen zur Klärung der Frage bei, warum weißgelbe Tabake im allgemeinen in einem viel kürzeren Zeitraum zur Reife gelangen als Blätter herkömmlicher grüner Tabaksorten.

\section{RESUME}

Des rondelles découpées dans des feuilles de tabac ont été soumises à différents types d'éclairage et de solutions chimiques afin de déterminer l'interaction de ces facteurs dans la sénescence des feuilles. Le rouge lointain provoque la sénescence plus rapidement que la lumière à longueurs d'ondes inférieures. Le magnésium à $50 \mathrm{mM}$ est un inhibiteur puissant de la sénescence tandis que le sel disodique d'EDTA a $50 \mathrm{mM}$ accélère celle-ci sous l'effet de la lumière mais la retarde dans l'obscurité. Des travaux supplémentaires sur l'effet de l'éthylène sur des fevilles détactiées ont démontré que l'activité des amylases, peptidases et protéases augmente sous l'effet de ce traitement mais que celle de l'estérase diminue. Les réactions diffèrent selon la variété des feuilles et leur maturité. L'exposition à l'éthylène augmente la concentration de l'oxidase d'acide chlorogénique dans les feuilles inférieures du tabac jaune pâle (pale yellow) mais la diminue dans les feuilles inférieures du NC-95. Ces données se rapportent à la croissance des deux génotypes dans la mesure où la maturité physiologique se produit avec une différence de rapidité considérable entre les plantes jaune pâle et NC-95. Les résultats contribuent a expliquer pourquoi les feuilles des plantes jaune pâle ont tendance d̀ mûrir plus rapidement que celles des cultivars verts ordinaires.

\section{REFERENCES}

1. Anderson, J. W., and K. S. Rowan: Biochem. J. 97 (1965) 741.

2. Aron, D.: Plant Physiol. 24 (1949) 1.

3. Chaplin, J. F.: Agron. J. 67 (1975) 354.

4. De Jong, D. W.: Plant Physiol. 50 (1972) 733.
5. DeJong, D. W., and W. G. Woodlief: Tob. Sci. 18 (1974) 105.

6. DeJong, D. W., and J. Lam, Jr.: Proceedings, American Chemical Society Symposium, 173rd Meeting, $1977,78$.

7. Fletcher, R. A., and N. O. Adedipe: 7th Int. Conf. Plant Growth Subst., Canberra, Australia, Proceed., 1970, 571.

8. Hawks, S. N., Jr.: Principles of flue-cured tobacco production; published by the Author, N. C. State Univ., Raleigh, N. C., 239 pp., 1970.

9. Kasamo, K.: Plant and Cell Physiol. 17 (1976) 1297.

10. Kotaka, S., and A. P. Krueger: Plant Physiol. 44 (1969) 809.

11. Martin, C., and K. Thimann: Plant Physiol. 49 (1972) 64.

12. Matile, P.: Experientia 30 (1974) 98.

13. Poovaiah, B. W., and A. C. Leopold: Plant Physiol. 51 (1973) 848.

14. Poovaiah, B. W., and A. C. Leopold: Plant Physiol. 52 (1973) 236.

15. Sisler, E. C., and A. Pian: Tob. Sci. 17 (1973) 68.

16. Skokut, T. A., J. H. Wu and R. S. Daniel: Photochem. Photobiol. 25 (1977) 109.

17. Tso, T. C.: Beitr. Tabakforsch. 9 (1977) 63.

18. Vonshak, A., and A. E. Ridhmond: Plant Physiol. 55 (1975) 786.

19. Weybrew, J. A., and R. C. Long: Tob. Sci. 14 (1970) 167.

20. Woolhouse, H. W.: Bioscience 28 (1978) 25.

21. Woodlief, W. G., and D. W. DeJong: Tob. Sci. 22 (1978) 116.

22. Wu, J. H., T. Skokut and M. Hartman: Photodem. Photobiol. 18 (1973) 71.

Autbors' address:

Tobacco Research Laboratory, U.S. Department of Agriculture, Science and Education Administration, Federal Research, Southern Region,

Route 2, Box $16 \mathrm{G}$,

Oxford, North Carolina, 27565, U.S.A. 